\title{
Managing Urban Parks for a Racially and Ethnically Diverse Clientele
}

\author{
PAUL H. GOBSTER \\ USDA Forest Service \\ North Central Research Station \\ Chicago, Illinois, USA
}

\begin{abstract}
A major planning effort for Chicago's largest park provided an opportunity to examine outdoor recreation use patterns and preferences among a racially and ethnically diverse clientele. Results from on-site surveys of 898 park users (217 Black, 210 Latino, 182 Asian, and 289 White) showed that park users shared a core set of interests, preferences, and concerns about the park and its management. But there were also some important differences among and within racial and ethnic groups with respect to park use patterns, participation, and reports of racial discrimination. Implications for management and future research are discussed.
\end{abstract}

Keywords ethnicity, urban parks, participation, preferences, social groups, discrimination

Two important goals of park managers are to provide physical and social settings and to manage facilities and programs that help park clientele have satisfying experiences (Hoots $\&$ Buist, 1982). Meeting these goals is not easy, especially in urban areas where park space is limited, use is high, and demand for activities is diverse. The difficulty is increased when the clientele itself is diverse. In large cities like Chicago, user groups can be very heterogeneous, and managers are increasingly challenged to understand and respond to the special needs and interests of older adults, young children, persons with disabilities, and other groups.

This article focuses on serving the needs and interests of racial and ethnic minority groups who use urban parks. Like the other groups mentioned, racial and ethnic minorities can differ from the general population, but research information and management guidelines for particular racial and ethnic groups are lacking (Dwyer \& Gobster, 1997). This is especially true for Latino and Asian groups, whose growing numbers make them increasingly important recreation customers in urban and wildland settings (Dwyer, 1994). Even when research is conducted, information on minority needs and interests often falls short. Many random samples of the general population in mail, telephone, and on-site surveys often do not contain enough minority respondents to produce reliable data; and even when they do, these surveys may not provide enough detail to answer questions specific to minority users (Floyd, 1999).

Received 18 February 2001; accepted 6 October 2001.

Thanks to Antonio Delgado and Tingwei Zhang for assisting with the ethnicity survey, and to Jeff Hayward for providing data for the general population survey.

Address correspondence to Paul H. Gobster at USDA Forest Service, 1033 University Pl \#360, Evanston, IL 60201. E-mail: pgobster@fs.fed.us 
One primary question is that of use. Although past findings show variation both within and among individuals and groups, there is a general tendency for White recreationists to travel further and visit urban and wildland parks and natural areas more frequently than African Americans (e.g., Dwyer, 1994; Scott \& Munson, 1994; Washburne, 1978). Travel and use patterns by individuals of Latino, Asian, or American Indian origin are less studied and seem to vary across sites and studies (e.g., Chavez, 2001), but one common thread in studies of Latino recreationists is a generally larger and more age-diverse social group (Gramann, 1996). These differences raise questions about various dimensions of access to recreation sites. In urban settings it would seem particularly important to understand how external factors such as costs and transportation alternatives and internal factors such as site facilities encourage or discourage use for a diversity of individuals.

Another important question pertains to activity participation, one of the most-studied aspects of leisure and recreation patterns among racial and ethnic minority groups. The majority of studies have identified lower rates of participation by African Americans as compared to Whites in wildland activities such as camping and hiking and higher participation in urban activities like ball playing and picnicking (e.g., Dwyer \& Gobster, 1997). While a continuing debate focuses on why such differences occur (e.g., Floyd, 1999), in an urban setting with high demands for use, one key issue for recreation managers may be to identify how to meet the core needs of all users while at the same time understanding how special needs and desires might be accommodated for particular groups.

While they are less studied, questions about environmental perceptions and preference are equally important to those of activity participation in understanding how parks can better function for a diverse range of racial and ethnic groups. Studies of this type reviewed by Kaplan and Talbot (1988) showed that African Americans generally preferred settings with higher levels of maintenance; more open, formal tree plantings; and higher levels of facility development than Whites. Both the Kaplan and Talbot review and Chavez's (2001) review of studies of Latino groups show a preference by racial and ethnic minorities for development and site arrangements that promote higher levels of social interaction within and among groups of users. These issues are central to park management in all types of settings, but in urban settings it may be equally important to know how sites are perceived negatively by different groups, particularly in terms of their safety.

This raises one final set of substantive issues for research, namely those relating to inter- and intragroup interactions and differences. Clearly, one key issue here is racial and ethnic discrimination (e.g., West, 1989), but questions about minimizing conflict and feeling comfortable in park settings with diverse users might also manifest themselves in how groups locate themselves within a space. As to questions of intraracial and ethnic differences, very little work has been done (e.g., Woodard, 1988; Carr \& Williams, 1993). This type of information would be of great value in park settings that draw diverse users, to help managers understand within-group diversity.

This research addressed these four major issues within the context of planning for a large urban park. Lincoln Park in Chicago was chosen as a study site because of the racial and ethnic diversity of its recreational users and because findings could serve an ongoing master planning effort for the park. Study objectives were to:

1. develop an on-site sampling design and interview procedure to survey racial and ethnic minority park users;

2. identify park users' patterns, activities, preferences, and perceptions of safety, and compare these findings across racial and ethnic groups; and,

3. identify minority-specific information about preferences for particular locations within the park, incidents of racial discrimination, and ethnicity. 


\section{Methods}

\section{Research Setting}

As Chicago's oldest, largest, and most heavily used park, Lincoln Park provides recreation and leisure opportunities to more than 20 million users annually (Chicago Park District, 1989). With five miles of Lake Michigan shoreline and over one-thousand acres of land, it is one of the largest and most scenic city parks in the nation. Originally developed in the 1860 s as a passive landscape park or pleasure ground in the tradition of Frederick Law Olmsted and his contemporaries (Cranz, 1982), its management philosophy has evolved to accommodate diverse uses and users. Besides many passive land and water activities, the park today also includes a zoo, a conservatory, two museums, three harbors, a nine-hole golf course, two field houses, three beach houses, and four beaches. Athletic facilities include 11 playgrounds, 16 ball diamonds, 9 football-soccer fields, 33 tennis courts, and a variety of paths. Many recreational programs are also offered. The park has several large parking lots and is easily accessible by foot and bicycle from adjacent neighborhoods, and by public transportation from more distant neighborhoods.

In 1990, because of constant demands for new uses and activities, the Chicago Park District began studies for its first master planning effort for the park in more than 40 years. Urban racial and ethnic minority users of Lincoln Park have increased greatly in recent years, and concern about their needs and interests was voiced by a citizens task force on recreation assembled by the Park District to help guide the master plan. Three general population surveys were initiated by the task force in summer 1990 to better understand recreational use of the park, including an on-site survey of park users (People, Places, and Design Research, 1991). But because the large majority of park use is by Whites, information on racial and ethnic groups in the on-site survey was too sparse for analysis. To better understand racial and ethnic minority park users, a follow-up survey was conducted the next summer.

\section{Survey Instrument}

The on-site survey instrument developed for the original study contained 14 items addressing use patterns, preferences, management concerns, and user demographics. The follow-up instrument included the same basic set of questions, but was expanded to address minorityspecific issues about preferred locations within the park, incidents of racial discrimination, and ethnicity. The survey was administered by interviewers except for the final questions on demographics, which were filled in by the respondent. A Spanish-language version was also produced. It was back translated to English to ensure the meanings of the terms were preserved.

\section{Sampling Design}

In the original sampling design, the park was divided into three major zones (south, middle, and north) and 30 subzones (e.g., beach, harbor, playfields). Interviews were conducted within each zone at various times of the day and days of the week to attain a representative cross-section of park users. During each sampling period, an interviewer made a sweep along a predetermined route through one of the subzones, and at a predetermined interval used a random procedure to solicit interviews from park users. As carried out, the sample was distributed in the following ways: location (54\% south, $28 \%$ middle, $14 \%$ north), time of day (12\% 8 A.M.-noon, $40 \%$ noon-4 P.M., 47\% 4-8 P.M.), and day of week (69\% weekday, $31 \%$ weekend). The final sample of 409 users provided a reasonable estimate of the proportion of different racial and ethnic groups who use the park: 71\% White, 12\% Black, 11\% Latino, 
$4 \%$ Asian, $2 \%$ other, and $1 \%$ missing data. Beyond this, however, the sample of 49 Blacks, 45 Latinos, and 16 Asians was too small to answer questions about minority groups.

The follow-up survey used a modified version of the original sampling design to increase the sample of minority park users. Sampling was weighted more heavily on the park's northern end because of the higher minority use there. Sweeps through subzones were made in a similar fashion, except only minority park users were targeted for interviews. An "ethnic team" concept was used, where Black interviewers interviewed Black park users, Latinos interviewed Latinos, and Asians interviewed Asians. This procedure, along with a day-long training session with the interviewers, helped to ensure a more comfortable conversation with park users, especially on sensitive topics such as discrimination. In some cases, this also helped to complete interviews with non-English-speaking park users. A quota of 167 interviews per ethnic team (500 total) was established, with guidelines given on how to spread the interviews out over time and space. As carried out, the sample was distributed in the following ways: location ( $24 \%$ south, $20 \%$ middle, $56 \%$ north), time of day ( $25 \% 8$ A.M.noon, 38\% noon-4 P.M., 30\% 4-8 P.M.), and day of week (38\% weekday, $62 \%$ weekend). While the results of the sampling did not mirror the original survey, there is reasonable confidence that the procedures attained a representative cross-section of minority users.

\section{Results}

Except where noted, this section reports combined results from the two surveys. A total of 911 interviews were completed. The refusal rate was less than $10 \%$, and most refusals were due to a lack of time or language differences. Completed surveys for the ethnicity study included 169 Black, 166 Latino, and 167 Asian park users. Thirteen questionnaires were excluded from the original survey because respondents were classified as "other," or because no racial/ethnic information was given. The final usable sample of 898 included 217 Black, 210 Latino, 182 Asian, and 289 White park users.

\section{Use Patterns}

On the whole, results showed that minority park users came from farther away to use the park, more often came by car, used the park less frequently, and were more likely to visit in large, family-oriented groups than White park users.

Distance to the park. Zip code data showed that $80 \%$ of White park users came from neighborhood s nearest the park, compared to around $60 \%$ of minority users. For the remaining $40 \%$ of minorities, many Blacks $(36 \%)$ came from neighborhoods south of the park, and many Latinos $(37 \%)$ came from west of park. Asian users were the most dispersed group, including $19 \%$ who were from the suburbs. Travel time estimates, solicited only in the minority survey, averaged 22 minutes for Blacks, 19 for Latinos, and 30 for Asians.

Mode of transportation. Travel distances may partly explain the differences between groups in how they reached Lincoln Park. A full 54\% of Whites walked to the park and only $30 \%$ drove. These figures were essentially reversed for Blacks and Latinos, while a large majority $(83 \%)$ of Asians drove and only a few $(9 \%)$ walked. Bicycling was an option chosen by $10 \%$ of both Blacks and Whites, and Latinos were the only group who used mass transit as a significant form of access $(20 \%)$.

Frequency of use. White users were the most frequent park users, with $42 \%$ reporting using the park "virtually everyday." Latinos were also frequent visitors; $37 \%$ visited "virtually every week," and another $24 \%$ "virtually everyday." Blacks and Asians ranged widely in their frequency of use; about a third of each group were light users (three times/year 
or less), a third moderate (4-25 times/year), and a third heavy users ( $>25$ times/year). There was a small, negative correlation between travel time and frequency of park use; those living further away from the park were likely to use it less often $(r=-.24, p<.001)$. Because travel time was asked only in the minority survey, it is not known if this relationship holds for White park visitors.

Social patterns of use. One big difference between racial/ethnic group use patterns was social group size and composition. Whites tended to use the park as individuals or couples, with an average group size of 1.6. Minority groups in contrast averaged 3.7 for Blacks, 4.4 for Latinos, and 5.0 for Asians. Significant numbers of Latinos and Asians came in large groups; more than $10 \%$ of each were using the park in groups larger than 10 .

Group type information was collected in the minority survey only. Although results showed that one-third to one-half of minority visits took place by individuals or couples, the survey also revealed the importance of family groups in the social patterns of minority users of Lincoln Park. Visits to the park by families accounted for $38 \%$ of park use by Blacks, $41 \%$ by Latinos, and $47 \%$ by Asians. In all cases, park use by the extended families - the immediate family plus close relatives - was the rule rather than the exception. This contrasts with the available information on White park users, $88 \%$ of whom either came alone or with one other person. Organized outings also figured significantly in the types of groups in which Blacks and Latinos used the park, with $11 \%$ of visits by each occurring in organized groups.

\section{Activity Participation}

Park users were asked two open-ended questions about their activities in the park the day of their interview and during other times and seasons. Their responses are categorized in Table 1.

Common activities. Results showed a core of activities that occur in the park regardless of race or ethnicity. These activities included walking, swimming or sunning at the beaches, picnicking and barbecuing, going to zoo, sitting and relaxing, and bicycling. Participation in these top activities, averaged over all groups, ranged from $27 \%$ for walking to $14 \%$ for bicycling. Some groups, however, were more likely than others to participate in these activities. More Whites, for example, walked and bicycled, more Latinos and Asians picnicked, and more Latinos visited the zoo than did other groups.

Group variations. Outside of the core activities were other pastimes that some groups participated in more than others. Like use patterns, these activities may help define cultural differences important in planning for particular groups. Some differences are best understood by the category grouping s shown below and in Table 1, others by the particular activity itself.

1. Passive activities -All minority groups were more likely to engage in passive, social park activities than Whites. As mentioned, picnicking was a frequent activity of Latinos and Asians; other frequent passive social activities included talking and socializing by Blacks, engaging in organized festivals and parties by Asians, and watching organized sports by Latinos.

2. Active-individual sports-Whites were the most involved in active-individual sports. Walking and bicycling have already been metioned; other activities in this category with high participation by Whites included jogging and walking the dog.

3. Active-group sports-All groups participated in active-group sports, but differed in some specific activities. Sports with high relative participation for different groups included 
TABLE 1 Things People Do in Lincoln Park

\begin{tabular}{|c|c|c|c|c|c|c|c|}
\hline $\begin{array}{l}\text { Response } \\
\text { categories }\end{array}$ & $\begin{array}{c}\% \\
\text { Black } \\
n=217\end{array}$ & $\begin{array}{c}\% \\
\text { Latino } \\
n=210\end{array}$ & $\begin{array}{c}\% \\
\text { Asian } \\
n=182\end{array}$ & $\begin{array}{c}\% \\
\text { White } \\
n=289\end{array}$ & $\begin{array}{c}\% \\
\text { All } \\
n=898\end{array}$ & $\begin{array}{c}N \\
\text { All }\end{array}$ & $\begin{array}{c}\chi^{2} \text { sig. } \\
(p)\end{array}$ \\
\hline Passive & 50.2 & 66.2 & 63.7 & 45.0 & 55.0 & 494 & 0.000 \\
\hline Sightseeing/hang out & 11.1 & 9.1 & 16.5 & 3.1 & 9.1 & 82 & 0.000 \\
\hline Sitting, relaxing, rest & 16.1 & 18.1 & 7.7 & 21.1 & 16.5 & 148 & 0.002 \\
\hline Taking in fresh air & .9 & 4.9 & .0 & .7 & 1.6 & 14 & $0.000^{a}$ \\
\hline Watch people, opp. sex & 8.3 & 4.3 & .6 & 6.2 & 5.1 & 46 & 0.004 \\
\hline Watch organized sports & 2.8 & 5.7 & 3.9 & 1.0 & 3.1 & 28 & 0.026 \\
\hline Talking, socializing & 7.8 & 4.8 & 2.8 & .7 & 3.8 & 34 & 0.000 \\
\hline Dating, affection & 1.8 & 3.3 & 1.1 & .4 & 1.6 & 14 & $0.059^{a}$ \\
\hline Picnicking, barbeque & 10.6 & 33.8 & 32.4 & 16.3 & 22.3 & 200 & 0.000 \\
\hline Festivals, parties & 1.8 & 3.3 & 14.8 & 2.1 & 4.9 & 44 & 0.000 \\
\hline Active-individual & 32.7 & 33.3 & 24.2 & 75.8 & 45.0 & 404 & 0.000 \\
\hline Walking & 16.6 & 18.1 & 13.2 & 50.2 & 2.1 & 243 & 0.000 \\
\hline Jogging, running & 3.2 & 7.6 & 4.4 & 18.3 & 9.4 & 84 & 0.000 \\
\hline Bicycling & 11.2 & 11.9 & 6.6 & 22.5 & 14.0 & 126 & 0.000 \\
\hline Rollerblade/skateboard & .0 & .0 & .0 & 3.5 & 1.1 & 10 & $0.000^{a}$ \\
\hline Exercising & 3.7 & 2.4 & 4.4 & 4.2 & 3.7 & 33 & 0.695 \\
\hline Walking the dog & 1.4 & 1.9 & 1.7 & 10.0 & 4.3 & 39 & 0.000 \\
\hline Active-group & 18.4 & 28.6 & 23.1 & 22.2 & 22.9 & 206 & 0.095 \\
\hline Playing soccer & .9 & 12.4 & 1.7 & .0 & 3.5 & 31 & 0.000 \\
\hline Playing baseball & 3.7 & 2.4 & 1.1 & 4.5 & 3.1 & 28 & 0.180 \\
\hline Playing basketball & 6.5 & 1.4 & .6 & .0 & 2.0 & 18 & $0.000^{a}$ \\
\hline Playing volleyball & .5 & 2.4 & 6.0 & 3.5 & 3.0 & 27 & 0.011 \\
\hline Playing tennis & .9 & 1.0 & 1.1 & 4.8 & 2.2 & 20 & $0.004^{a}$ \\
\hline Playing football & .0 & .5 & .6 & .0 & .2 & 2 & $0.456^{a}$ \\
\hline Playing golf & 1.4 & 1.0 & 6.6 & 6.6 & 4.0 & 36 & 0.001 \\
\hline Playing oth. org. sports & 2.8 & 2.9 & 1.7 & 1.0 & 2.0 & 18 & $0.406^{a}$ \\
\hline Children playing & .5 & .2 & 1.7 & .4 & 2.0 & 18 & 0.000 \\
\hline Playing games & 1.8 & .0 & 1.1 & 3.5 & 1.8 & 16 & $0.030^{a}$ \\
\hline Playing Frisbee & .5 & 2.4 & 1.7 & 1.7 & 1.6 & 14 & 0.441 \\
\hline Water sports & 18.0 & 38.6 & 25.8 & 39.1 & 31.2 & 280 & 0.000 \\
\hline Swimming, sun on beach & 13.8 & 33.8 & 15.9 & 35.0 & 25.7 & 231 & 0.000 \\
\hline Fishing & 3.2 & 4.3 & 9.3 & 2.4 & 4.5 & 40 & 0.003 \\
\hline Boating, watch boats & 1.4 & 1.0 & .6 & 3.8 & 1.9 & 17 & $0.033^{a}$ \\
\hline \multicolumn{8}{|l|}{ Miscellaneous } \\
\hline Zoo, watch zoo animals & 10.6 & 28.6 & 12.6 & 18.3 & 17.7 & 159 & 0.000 \\
\hline Museums, conservatory & .9 & 1.9 & .0 & 2.1 & 1.3 & 12 & $0.216^{a}$ \\
\hline Birding, feed birds & .0 & .0 & 6 & 1.4 & .6 & 5 & $0.113^{a}$ \\
\hline Commuting through park & .9 & 1.0 & 6 & .0 & .6 & 5 & $0.435^{a}$ \\
\hline Working, studying & .5 & 1.0 & 2.2 & 1.4 & 1.2 & 11 & $0.447^{a}$ \\
\hline
\end{tabular}

${ }^{a}$ Results of the $\chi^{2}$ significance test for this activity may be unreliable because 1 or more groups had low participation rates (5 individuals or less).

basketball for Blacks; soccer for Latinos; volleyball and golf for Asians; and golf, tennis, and game playing for Whites.

4. Water-oriented activities - Participation in water sports among groups varied by activity. As previously mentioned, Whites and Latinos were more active in swimming; Asians were more active in fishing, and Whites were more active in boating activities than were other groups. 
As a measure of how similar the groups were in activity participation, the rank order of activities was correlated between each group. The highest correlation was between Blacks and Latinos, with $r_{\mathrm{s}}=.69$. The lowest correlation was between Whites and Latinos, with $r_{\mathrm{s}}=.35$.

\section{Site Preferences and Perceptions of Safety}

Open-ended questions were used to identify what park users liked and didn't like about Lincoln Park. Their responses are categorized in Tables 2 and 3. Respondents were also asked if they felt safe in the park and under what conditions they felt unsafe.

TABLE 2 Things People Like About Lincoln Park

\begin{tabular}{|c|c|c|c|c|c|c|c|}
\hline $\begin{array}{l}\text { Response } \\
\text { categories }\end{array}$ & $\begin{array}{c}\% \\
\text { Black } \\
n=217\end{array}$ & $\begin{array}{c}\% \\
\text { Latino } \\
n=210\end{array}$ & $\begin{array}{c}\% \\
\text { Asian } \\
n=182\end{array}$ & $\begin{array}{c}\% \\
\text { White } \\
n=289\end{array}$ & $\begin{array}{c}\% \\
\text { All } \\
n=898\end{array}$ & $\begin{array}{c}N \\
\text { All }\end{array}$ & $\begin{array}{c}\chi^{2} \text { sig. } \\
(p)\end{array}$ \\
\hline Natural environment & 37.9 & 61.4 & 70.9 & 61.3 & 57.4 & 515 & 0.000 \\
\hline Beauty, scenery, view & 2.8 & 4.8 & 18.1 & 5.5 & 7.2 & 65 & 0.000 \\
\hline Nature, natural env. & 1.4 & 2.9 & 2.8 & 1.0 & 1.9 & 17 & $0.361^{a}$ \\
\hline Wide, open space & 3.7 & 10.5 & 7.1 & 9.7 & 7.9 & 71 & 0.035 \\
\hline Trees and other veg. & 3.2 & 11.1 & 8.8 & 18.7 & 11.1 & 100 & 0.000 \\
\hline Lake, shoreline, water & 8.3 & 24.8 & 30.8 & 25.3 & 22.2 & 199 & 0.000 \\
\hline Beach, sand & 17.1 & 16.7 & 20.9 & 6.6 & 14.4 & 129 & 0.000 \\
\hline Birds, animals & .0 & .5 & 1.1 & .4 & .5 & 4 & $0.425^{a}$ \\
\hline Sun, sunrise, weather & 3.2 & 1.4 & 1.7 & .7 & 1.7 & 15 & $0.175^{a}$ \\
\hline Fresh air, lake effect & 2.3 & 10.0 & 4.4 & 3.8 & 5.0 & 45 & 0.002 \\
\hline Contrast of park w/city & .9 & .5 & .0 & 5.2 & 2.0 & 18 & $0.000^{a}$ \\
\hline $\begin{array}{l}\text { Cultural facilities } \\
\text { \& maintenance }\end{array}$ & 35.9 & 21.9 & 13.2 & 28.7 & 25.7 & 231 & 0.000 \\
\hline City views, skyline & .0 & .0 & 1.7 & 1.0 & .7 & 6 & $0.107^{a}$ \\
\hline Zoo & 23.0 & 8.6 & 5.0 & 6.2 & 10.6 & 95 & 0.000 \\
\hline Park buildings & .5 & .5 & .6 & 3.1 & 1.3 & 12 & $0.017^{a}$ \\
\hline Play courts and fields & 3.7 & 5.2 & 2.2 & 1.0 & 2.9 & 26 & 0.038 \\
\hline Biking/jogging paths & 7.4 & 2.9 & 2.2 & 8.7 & 5.7 & 51 & 0.004 \\
\hline $\begin{array}{l}\text { Cleanliness/ } \\
\text { maintenance }\end{array}$ & 2.8 & 5.2 & 2.8 & 10.4 & 5.8 & 52 & 0.000 \\
\hline Safety, security & .9 & 1.0 & .0 & 2.8 & 1.3 & 12 & $0.058^{a}$ \\
\hline Activities and events & 27.2 & 12.9 & 9.3 & 12.8 & 15.6 & 140 & 0.000 \\
\hline Seeing people/activity & 11.1 & 9.1 & 6.6 & 11.1 & 9.7 & 87 & 0.363 \\
\hline Picnics, festivals & 5.1 & 1.0 & 3.3 & .7 & 2.3 & 21 & $0.005^{a}$ \\
\hline Watching/doing sports & 11.5 & 3.3 & 2.2 & 1.0 & 4.3 & 39 & 0.000 \\
\hline \multicolumn{8}{|l|}{ Miscellaneous } \\
\hline $\begin{array}{c}\text { Peaceful, friendly } \\
\text { atmosphere }\end{array}$ & 12.4 & 7.1 & 3.3 & 13.8 & 9.8 & 88 & 0.001 \\
\hline Good, close location & 6.5 & 5.2 & 4.4 & 10.4 & 7.0 & 63 & 0.045 \\
\hline Like it all, fun place & 4.2 & 3.3 & 2.2 & .7 & 2.5 & 22 & 0.069 \\
\hline
\end{tabular}

${ }^{a}$ Results of the $\chi^{2}$ significance test for this item may be unreliable because 1 or more groups had few individuals mentioning it (5 or less). 
TABLE 3 Things People Dislike About Lincoln Park

\begin{tabular}{|c|c|c|c|c|c|c|c|}
\hline $\begin{array}{l}\text { Response } \\
\text { categories }\end{array}$ & $\begin{array}{c}\% \\
\text { Black } \\
n=217\end{array}$ & $\begin{array}{c}\% \\
\text { Latino } \\
n=210\end{array}$ & $\begin{array}{c}\% \\
\text { Asian } \\
n=182\end{array}$ & $\begin{array}{c}\% \\
\text { White } \\
n=289\end{array}$ & $\begin{array}{c}\% \\
\text { All } \\
n=898\end{array}$ & $\begin{array}{c}N \\
\text { All }\end{array}$ & $\begin{array}{l}\chi^{2} \text { sig. } \\
(p)\end{array}$ \\
\hline $\begin{array}{l}\text { Facilities/management } \\
\text { problems }\end{array}$ & 41.9 & 40.0 & 48.9 & 50.5 & 45.7 & 410 & 0.059 \\
\hline Lacks maintenance & 3.7 & 2.4 & 1.1 & 4.2 & 3.0 & 27 & 0.241 \\
\hline $\begin{array}{l}\text { Not enough nature, } \\
\text { trees }\end{array}$ & 6.0 & .5 & 2.2 & 3.1 & 3.0 & 27 & 0.009 \\
\hline $\begin{array}{l}\text { Bad air or water } \\
\text { quality }\end{array}$ & .9 & .0 & .0 & 2.8 & 1.0 & 10 & $0.009^{a}$ \\
\hline $\begin{array}{l}\text { Need more/cleaner } \\
\text { restrooms }\end{array}$ & 6.5 & 19.1 & 8.8 & 3.8 & 9.0 & 81 & 0.000 \\
\hline Path condition/length & 2.3 & .5 & .6 & 3.5 & 1.9 & 17 & $0.045^{a}$ \\
\hline $\begin{array}{l}\text { Beach condition } \\
\text { closed areas }\end{array}$ & .9 & .5 & .0 & 2.4 & 1.1 & 10 & $0.060^{a}$ \\
\hline Litter and vandalism & 17.1 & 17.1 & 24.7 & 35.6 & 24.6 & 221 & 0.000 \\
\hline Lack of facilities & 3.2 & 10.5 & 1.1 & 2.8 & 4.3 & 39 & 0.000 \\
\hline Lack of parking & 2.3 & 5.2 & 11.5 & 3.1 & 5.1 & 46 & 0.000 \\
\hline Cost of food, parking & 3.2 & 1.0 & .6 & 1.0 & 1.5 & 13 & $0.099^{a}$ \\
\hline $\begin{array}{l}\text { Lack of information } \\
\text { programs }\end{array}$ & 1.8 & 1.4 & .6 & 1.0 & 1.2 & 11 & $0.676^{a}$ \\
\hline $\begin{array}{l}\text { Social and user } \\
\text { problems }\end{array}$ & 30.0 & 15.7 & 22.0 & 50.5 & 31.6 & 284 & 0.000 \\
\hline Lack of security & 4.6 & 1.4 & .6 & 6.9 & 3.8 & 34 & 0.001 \\
\hline Crowded & 1.4 & 4.3 & 9.9 & 17.3 & 8.9 & 80 & 0.000 \\
\hline Cars and traffic & .5 & .0 & .6 & 2.8 & 1.1 & 10 & $0.012^{a}$ \\
\hline Trail user conflicts & .5 & .0 & 1.1 & 9.0 & 3.2 & 29 & 0.000 \\
\hline Loud and rude users & 4.2 & 1.9 & 5.5 & 5.5 & 4.3 & 39 & 0.204 \\
\hline Pet problems & 2.8 & .5 & 1.7 & 3.8 & 2.3 & 21 & $0.091^{a}$ \\
\hline $\begin{array}{l}\text { Drunks and drug } \\
\text { users }\end{array}$ & 3.2 & 3.3 & 2.8 & 1.7 & 2.7 & 24 & 0.660 \\
\hline $\begin{array}{l}\text { Gangs and drug } \\
\text { dealers }\end{array}$ & 3.2 & 2.4 & 1.1 & 2.8 & 2.5 & 22 & 0.559 \\
\hline $\begin{array}{r}\text { Police/staff } \\
\text { behavior }\end{array}$ & 6.0 & 2.4 & .0 & .7 & 2.2 & 20 & $0.000^{a}$ \\
\hline $\begin{array}{l}\text { Racial problems/ } \\
\text { prejudice }\end{array}$ & 6.5 & .0 & .0 & 1.0 & 1.9 & 17 & $0.000^{a}$ \\
\hline $\begin{array}{l}\text { Homeless/strange } \\
\text { people }\end{array}$ & .9 & .5 & .6 & 8.3 & 3.1 & 28 & 0.000 \\
\hline \multicolumn{8}{|l|}{ Miscellaneous } \\
\hline $\begin{array}{l}\text { Parking, access } \\
\text { problems }\end{array}$ & .0 & .5 & 5.5 & 1.0 & 1.6 & 14 & $0.000^{a}$ \\
\hline
\end{tabular}

${ }^{a}$ Results of the $\chi^{2}$ significance test for this item may be unreliable because 1 or more groups had few individuals mentioning it (5 or less). 
Favored park attributes. Top responses common to all groups included: lake and ponds; beaches; zoo; peaceful, friendly atmosphere; people and varied activities; and the park's proximity to the lake and to people's homes (Table 2). Many people mentioned the park's natural features, but groups differed in the attributes they favored. Asians mentioned the park's scenic beauty more often than other groups, Latinos the cool refreshing "lake effect," and Whites the trees and other park vegetation. Blacks said less about the natural environment, instead focusing on facilities and maintenance aspects, park activities, the zoo, and the sports orientation. Rank order correlations showed that Asians and Latinos had the most similar preferences $\left(r_{\mathrm{s}}=.87\right)$, while Blacks and Whites had the least $\left(r_{\mathrm{s}}=.43\right)$.

Disliked park attributes. Litter and vandalism and the need for more and cleaner restrooms were top problems mentioned by all groups (Table 3). Other problems varied between groups: Asians mentioned parking and park access problems more than other groups; Latinos the restrooms and lack of other facilities; Whites crowding, user conflicts, and the homeless; and Blacks prejudicial behavior of other users, park staff, and police. Rank order correlations between groups again showed Asians and Latinos the most similar to each other $\left(r_{\mathrm{s}}=.60\right)$, and Blacks and Whites the least $\left(r_{\mathrm{s}}=.06\right)$.

Perceptions of safety. Whites were more than twice as likely as other groups to say the park was unsafe; nearly half (47\%) of Whites mentioned places where they felt unsafe. Being in the park after dark or using poorly lit areas, especially when alone, were top responses given for when and where users would feel unsafe. This was true for all groups, but again more Whites (30\%) mentioned it as a reason than other groups (Asians 14\%, Blacks and Latinos 7\% each). There was not a strong consensus among users nor were there major differences between groups on particular places considered unsafe, except for the roadway underpasses.

\section{Racial and Ethnic Minority Issues and Concerns}

In this section I report on minority-specific questions asked only in the follow-up survey.

Favored locations in the park. Many respondents said they knew of popular areas in the park where members of their racial or ethnic group went, including $43 \%$ of Blacks, $51 \%$ of Latinos, and $82 \%$ of Asians. These places were spread throughout the park, but tended to center on a few locations and types of places. Locations near the north end of the park were most often mentioned by all three groups, but this finding may be confounded by the fact that respondents were more heavily sampled there. With this proviso in mind, however, there were still some distinct differences between groups with respect to specific northerly locations. Blacks (12\%) referred to a northerly beach area; Asians (10\%) mentioned areas to the south of that, and Latinos (14\%) further south yet. Of the types of locations, Blacks most often mentioned facility-related locations like ball courts and field houses, while Latinos more often referred to the lakeshore. Although many Asians mentioned knowing places popular for members of their group, few mentioned particular types or locations.

Racial/ethnic discrimination. A question on racial/ethnic discrimination in the park was asked directly: "In your past use of the park were there any times or situations where you felt discriminated against because of your race or ethnic background?" Interviewers then probed about specific circumstances, locations, and times. One in 10 respondents said they had been discriminated against in the park; reports were highest among Blacks (14\%), and somewhat less for Latinos (7\%) and Asians (9\%). Three identified sources of discrimination were reported: other users $(4 \%)$, police $(4 \%)$, and facilities or staff $(0.5 \%)$. Unidentified sources amounted to $1.5 \%$ of the $10 \%$ average total for all minority groups. Discrimination 
TABLE 4 Ethnic Groups Represented in the Survey

\begin{tabular}{lrlrlr}
\hline \multicolumn{1}{c}{$\begin{array}{c}\text { Black groups } \\
n=169\end{array}$} & \multicolumn{2}{c}{$\begin{array}{c}\text { Latino groups } \\
n=162\end{array}$} & \multicolumn{2}{c}{$\begin{array}{c}\text { Asian groups } \\
n=152\end{array}$} & $\%$ \\
\hline Northern U.S. roots & 58.0 & Mexican & 66.7 & Filipino & 24.3 \\
Southern U.S. roots & 38.4 & Puerto Rican & 9.3 & Chinese & 18.4 \\
African & 1.2 & Cuban & 1.2 & S.E. Asian (total) & 36.8 \\
West Indies & 2.4 & C/S America (total) & 19.1 & Vietnamese & 3.9 \\
& & Guatemalan & 7.4 & Cambodian & 1.3 \\
& & Salvadoran & 1.9 & Laotian & 2.0 \\
& & Costa Rican & .6 & Thai & 6.6 \\
& & Nicaraguan & .6 & Korean & 22.3 \\
& & Panamanian & .6 & S. Asian (total) & 8.6 \\
& & Columbian & 2.5 & Indian & 5.9 \\
& & Ecuadorian & 1.9 & Pakistani & 2.7 \\
& & Peruvian & 2.5 & Japanese & 8.6 \\
& & "American"; no & 3.7 & "American"; no & 3.3 \\
& & & ethnicity identified & \\
\hline
\end{tabular}

from other users included verbal harassment, physical gestures or assaults, and nonverbal messages resulting in a feeling of discomfort. Police-related incidents included verbal harassment and complaints about being treated unequally compared to Whites. Reports of facilities and staff-related discrimination mentioned unfair treatment of minorities and an unequal distribution of facilities in predominantly White versus predominantly minority areas of the park.

Ethnicity of park users. Results so far have been reported by race and Latino origin, but findings suggest important distinctions might also occur due to culture or ethnicity. In response to an open-ended question about ethnicity, park users identified themselves as belonging to 25 different ethnic groups. These included large, long-established Chicago ethnic groups such as Mexicans and Filipinos and smaller groups of more recent immigrants from countries in Africa, Central and South America, and South and Southeast Asia (Table 4). Blacks who have lived in the U.S. for many generations are sometimes considered culturally homogeneous, but some research suggests differences within Black communities of northern cities such as Chicago between those with long-established ties to the northern U.S. and those who (or whose parents) moved to the north from the south (Woodard, 1988). So a question about these regional ties was also asked of Black respondents.

Because of small sample sizes, comparison between some ethnic groups may be unreliable, but for the larger ethnic groups or regional groupings (Central and South American, Southeast Asian) some preliminary comparisons can be made:

1. Blacks-Subgroups included Blacks with northern and recent southern roots. In terms of use patterns, Blacks with recent southern roots lived in neighborhoods closer to the park, more often traveled there on foot (34\% vs. 19\%), and were more likely to frequent the park on a weekly or daily basis ( $42 \%$ vs. $20 \%$ ) than Blacks with northern roots. Activity participation also differed; those with southern roots were more likely to fish (5\% vs. $1 \%)$, swim (14\% vs. $6 \%$ ), and picnic (12\% vs. $4 \%)$ in the park, while those with northern roots were more likely to bicycle (14\% vs. $5 \%$ ) and golf ( $2 \%$ vs. $0 \%$ ).

2. Latinos - There were few differences in use patterns among Latino groups, but Mexicans, Puerto Ricans, and Central and South Americans did differ in some of the activities 
they pursued in the park. The biggest difference of these was soccer, played by $26 \%$ of Central and South Americans, $14 \%$ of Mexicans, and no Puerto Ricans. In other activities, basketball was played more by Puerto Ricans (7\%) and Central and South Americans (6\%) than by Mexicans (1\%); there was more swimming among Puerto Ricans $(47 \%)$ than Mexicans (31\%) or Central and South Americans (23\%); and more picnicking by Mexicans (40\%) and Central and South Americans (32\%) than by Puerto Ricans (13\%).

3. Asians-Asians had the most diverse use patterns and activity participation, perhaps reflecting the number of different groups for which there were data to compare and possible variation in the average length of time that each group had been in the United States. The Japanese had the most unique use patterns; they lived closest to the park, had the highest proportion who came on foot $(31 \%)$, and were weekly or daily users $(46 \%)$. Filipinos stood out among the Asian groups in their social use of the park; they were more likely to use the park in organized groups (14\%) and to come in large parties of 11 or more $(27 \%)$. Fishing was mentioned relatively frequently by Filipino and Southeast Asian groups (16\% each), but not at all by any of the other groups. Volleyball was mentioned by some Filipino (11\%), Japanese (15\%), and Chinese (7\%) park goers, but not by other groups. Golf was an activity for some Southeast Asians (14\%) and Japanese $(8 \%)$, but not for other groups. Finally, picnicking and barbecuing was a more frequent activity of Filipinos (62\%), South Asians (46\%), and Chinese (36\%) than of other groups.

\section{Discussion and Implications for Management and Research}

Three general points should be made at the outset. First, although this article describes many differences between groups, there was also a great deal of similarity: a common core of high participation activities, a shared preference for the park's natural features, a strong concern for cleanliness and maintenance, and a common perception about park safety. Second, many differences are of relative magnitude; there were few activities popular for one group that were not also participated in by some from other groups. Third, use patterns and preferences varied within racial groups as well between them, and to state unequivocally that "Blacks do..." or "Whites come from ..." would be to risk stereotyping.

These points are important in interpreting the study's findings and guiding how the results can and should be applied. For some findings, sharp distinctions between different groups may suggest clear changes in management policies, and failure to make such changes may result in mediocrity and the perpetuation of existing problems. In other cases, it may be difficult to suggest how a park might be managed differently given significant variations in uses and preferences across groups. In either case, information from studies like this can help challenge our premises about park use and preferences and may lead to more desirable and equitable decisions about park design and management.

\section{Access and Park Use}

Access to park opportunities is a key planning and management issue (Allison, 1992), and findings from this study raise questions about the relationship between urban park use and access to the unique opportunities that some parks provide. While other studies of park use tend to show that Whites often travel further distances to recreate than minority groups (e.g., Dwyer \& Hutchison, 1990; Metro, Dwyer, \& Dreschler, 1981), in the case of Lincoln Park, the pattern is reversed. Many Black, Latino, and Asian park users live in neighborhoods farther from the park than White users, and in this respect the findings suggest some potential constraints to physical site access by minorities. For these minority groups, Lincoln Park is a regional attraction, whereas most White users come from local neighborhoods. Park 
characteristics favored by users-a pleasant social atmosphere, scenic lake front location, and a host of developed facilities - contribute to the regional draw of minority users, who may not find similar alternatives closer to their homes. Distance to the park, combined with larger, family-oriented groups, can restrict transportation alternatives. The automobile in these cases becomes an important means of reaching the park, and for some visitors, especially Asians, parking was reported as a problem hampering access. Planners should recognize that proposed reductions in parking could disproportionately impact some groups. For other users, including a significant percentage of Latinos, mass transit appears to be a viable option. Further study of user origins could help identify likely travel routes to and within the park to facilitate and expand mass transit use.

\section{Participation and Preferences}

Studies of activity participation have tended to focus on Black-White comparisons (e.g., Dwyer \& Hutchison, 1990; Washburne, 1978), though more recent work has included a wider range of racial and ethnic groups (e.g., Baas, Ewert, \& Chavez, 1993; Dwyer, 1994). Researchers have attempted to explain differences in participation in terms of marginality (e.g., socioeconomic constraints) and ethnicity (e.g., cultural styles and preferences) factors (e.g., Floyd, Shinew, McGuire, \& Noe, 1994; Washburne, 1978). Although there was no direct test of these theories in the present study, the on-site survey approach used might have helped reduce some of the marginality factors that can influence participation-the costs of getting to the park have already been made, and in an urban setting such as Lincoln Park most activities require little equipment cost or user fees. Even with these marginality factors reduced, there still were substantial differences in activity participation between groups interviewed in the park. Whites outranked other groups in active-individual pursuits such as walking, bicycling, jogging, and walking the dog, and were outranked by other groups in passive, social activities such as picnicking, sightseeing, socializing, and attending festivals and parties. Significant differences in participation between groups-in 24 out of 34 activities_-suggest there may be important variations in participation due at least in part to racial/ethnic preferences.

Studies of environmental and development preferences have also tended to focus on Black-White comparisons (see review by Kaplan \& Talbot, 1988) except for some recent work (e.g., Baas, 1992; Blahna, 1992). Environmental perception studies generally show that Blacks and Whites both have a high regard for nature and trees in urban areas but the Blacks generally prefer higher levels of maintenance and order, more formal designs, greater openness and visibility; and are less critical of development or built elements that Whites might consider intrusions (Kaplan \& Talbot, 1988). Recreation preference studies complement the perception work and show a greater orientation of minority groups to developed facilities and amenities that promote social interaction (Baas, 1992; Blahna, 1992; Dwyer \& Gobster, 1992; Dwyer \& Hutchison, 1990). The findings in this study concur partially with this earlier research, but hint that differences in environmental and development preferences may be more complex than previously thought. As with the earlier research, Blacks were less likely than Whites to mention natural park attributes as preferred and more likely to mention facilities and social activity. However, Latinos and Asians tended to put emphasis as great or greater than Whites on the scenic view, open space, trees, water, and other natural attributes. Nonvisual attributes of the park experience were also important to certain groups; a significant number of Latinos mentioned "taking in the fresh air" as a favored activity, and "fresh air" or "lake effect" as a favored park attribute. These responses suggest sensory dimensions that may be important to some groups but that would be missed in visual perception assessments. Further research should investigate 
cross-cultural differences in environmental perception using more diverse populations and a wider range of sensory dimensions and analytical methods than in the past.

One area where site development and management can be of critical importance to urban park users is in relation to personal safety. In the Lincoln Park study, this issue was of particular importance to White park users, who were more than twice as likely to feel unsafe in the park than the other groups surveyed. Brighter lighting, increased police and citizen patrols, effective vegetation management to increase sight lines, and promoting activity in sparsely used areas are some important ways that personal safety can be increased in urban park settings (e.g., Loewen, Steel, \& Suedfeld, 1993; Schroeder \& Anderson, 1985).

Research that identifies racially/ethnically based differences in activities and preferences may support the implementation of policies and programs that meet the interests of individual groups. Instead of planning solely for the majority, data from the study show that a more equitable strategy would identify what different groups like and do, and would integrate these preferences and activities into current programs and budgets. For Lincoln Park, management that maintains and upgrades the passive landscape and facilitates social interaction-picnic areas, seating, the sidelines of sports fields-will improve conditions for all park goers. Enhancing natural landscape features such as trees, water bodies, and beaches should also be looked at as a priority since it supports the needs of all groups. The quality of active group facilities, notably basketball courts, soccer fields, and playgrounds, should also be maintained due to their centrality to some groups.

\section{Social Action and Interaction}

Social patterns of park use by Blacks, Latinos, and Asians also showed distinct differences from those of White users. These results are supported by studies examining preferences for social interaction (e.g., Dwyer \& Gobster, 1992), participation motivations (e.g., Gramann, Floyd, \& Saenz, 1993), and in-park use observations (e.g., Gobster, 1992; Hutchison, 1987). These studies generally show higher group sizes for non-White park users, and family and extended family group types for Latinos. Hutchison (1987) argued that the social composition of recreation groups may be a more important factor than activity participation in understanding the leisure of different ethnic and racial groups, and Floyd (1999) adds that the total combination of social patterns, activity preferences, and attitudes ultimately define unique leisure styles. Management that facilitates racially/ethnically based social use patterns might include table and seating arrangements that accommodate larger groups; a simplified information/permitting system for obtaining picnic areas for organized group festivals; and location and maintenance of restroom facilities throughout the park that provide safe and clean access.

Although social interaction was found to be an important aspect of minority park use, results also suggest that most interaction takes place within rather than between groups. Some racial/ethnic gathering spots mentioned by park goers were very clearly delineated; this was also evident in observations made during field sampling. A few users reported interethnic conflicts from crossing racial/ethnic group boundaries: "Three weeks ago I was knocked off my bike because seven White guys said I was in the "wrong area"; "When there's a group of us picnicking here, people observe 'us' in a way that makes us feel uncomfortable."

The management implications of use segregation are unclear, for segregation can have both positive and negative effects. Kornblum and his colleagues (National Park Service, 1975) found a similar pattern of segregation in their study of Gateway National Recreation Area, New York-New Jersey, and concluded such boundaries "allow users with different cultural and ethnic lifestyles to co-exist with a minimum of conflict" (p. 30). But they also 
found that boundaries can be problems if perceived ownership of an area inhibits others from using facilities in it that are not found elsewhere.

\section{Discrimination}

Interethnic user conflict is part of a larger problem for minorities who use parks, namely discrimination. Discrimination is a serious issue in park management, and has begun to receive some attention by leisure researchers (e.g., Blahna \& Black, 1993; Chavez, 1993; Floyd \& Gramann, 1995; West, 1989). In its mildest forms, discrimination can make users feel uncomfortable and lower their enjoyment of their recreation experience. At higher levels it can generate anger and physical violence, and result in user displacement or nonuse by some groups altogether. Although questions relating to discrimination were not asked on the original survey, it is likely that feelings of discomfort or fear can act as a deterrent to park use among Whites as well as racial and ethnic minority individuals (e.g., Gobster, 1998a), and might also play an important role in the marginalization of groups because of other factors such as age, gender, or sexual orientation.

Of the three sources of discrimination identified in the study, those stemming from police and from park staff and facilities may be the most treatable. Police and park supervisors should make their staffs more sensitive to the possibilities that their language and actions can discriminate against certain groups, or be perceived as such. For example, several Black males reported being stopped in the park by police and searched because they were carrying duffel bags, and felt they were under suspicion for selling drugs simply because they were Black males. Several Latinos also reported being hassled or arrested for having alcohol (illegal in the park), while Blacks and Whites nearby who were also drinking alcohol were left alone. Police should not stop doing their job, but how they do it could make a difference. By treating all park users equitably and courteously, police and park staff could help minimize actual and perceived discrimination against minority users.

Awareness and sensitivity training could help minimize discrimination, but sometimes a stronger commitment is needed. In parks like Lincoln with large concentrations of certain minority groups, staff of the same race/ethnicity, and in some cases those who speak the same language, could go far in serving clientele and lessening discrimination, real and/or perceived. This might require new hiring, but in large park districts this might be handled through employee relocation.

There was only one complaint about facility inequities in the study, but given the size of the park and the significant segregation of minority groups, possibilities exist for an uneven distribution of opportunities. Park managers should investigate the quantity and quality of facilities, services, programs, and staff throughout the park, paying particular attention to areas that serve minority clientele. Racially based "park equity" (Brune, 1978) can be seen as part of the larger concern for "environmental equity" (e.g., Bullard \& Wright, 1990). Like the environmental equity movement, as grass roots groups voice concerns about their park and recreation needs, more demands will be placed on park managers. By taking a proactive approach to meeting the needs of all groups based on surveys and other forms of outreach, managers can avoid negative reactions and charges of inequities.

Discrimination is a sensitive issue and is difficult to address in a survey. West (1989) was one of the first to identify racism and prejudice as barriers to urban park use by Blacks, and suggested that his telephone survey may have only uncovered "the tip of a larger iceberg, and that a larger percentage of respondents may have been affected by this than the number who would talk about these matters to a stranger over the phone" (p. 22). For similar reasons, on-site interviews may not have uncovered the full extent of problems occurring in Lincoln Park. It is likely, however, that the findings identified the principal sources and types of 
discrimination, and that park managers can begin to take positive steps to counteract some of them. Future research, including in-depth interviews with individuals and small groups, may be another way to get information about discrimination. Such research might also involve park staff and police, to better understand their perspectives and the way they deal with issues where the possibility of discrimination exists.

\section{Ethnicity}

As a final discussion point, these findings support the thesis that in some cases racial groupings may be too broad to identify culturally based differences in leisure behavior (Taylor, 1993). Hutchison (1988), in his critique of research in this area, argued that future work "must include population subgroups which contain ethnic subcultures, and must develop a research methodology capable of the capturing the very significant social phenomenon under study" (p. 25). This was attempted in the present study, but the quota sampling method limited analysis to sketchy ethnic comparisons in the same way a random sampling of the general population has limited others to sketchy racial comparisons. In follow-up research to this study, we used focus groups with individuals representing a selected cross-section of ethnic minority groups in Chicago, to more precisely identify ethnic leisure interests and needs (Delgado, 1994; Gobster, 1998b; Zhang \& Gobster, 1998). Results have helped to gain a more complete view of racial and ethnic leisure patterns and preferences.

As far as management implications are concerned, this research has helped to identify the wealth of ethnic and cultural diversity present in Lincoln Park. This diversity in itself should be something to let others know about. In some ways the park serves as a logical center of activity for festivals or a cultural center that celebrates the multicultural population of park users. If done correctly, these activities could help foster a better understanding between park users of diverse ethnic backgrounds and help reduce discrimination (Dawson, 1991).

\section{Conclusions}

This research has examined the use patterns, preferences, and perceptions of racial and ethnic groups who use a large city park. As a case study, the findings demonstrate the variations between users of different races, and to some extent, those of different ethnicities. More research in this area is needed, and qualitative, ethnographic methods may be the logical way to explore in depth the meaning and values that leisure experiences have for different cultural groups (Allison, 1988). On a pragmatic level, the study also demonstrates how onsite surveys of special populations can be integrated with more broad-based on-site surveys to provide a picture of park clientele interests and needs that extend beyond the average user. In Lincoln Park, ethnic minority groups were identified as an important population deserving of further study; in other parks and regions these groups might include older adults, children, persons with disabilities, and important activity-based user groups like trail users of boaters. By reaching out to these groups through research and related activities, planners and managers can make more informed and equitable decisions about how best to serve their diverse clientele.

\section{References}

Allison, M. (1988). Breaking boundaries and barriers: Future directions in cross-cultural research. Journal of Leisure Research, 10, 247-259.

Allison, M. T. (1992). Access and boundary maintenance: Serving culturally diverse populations. In A. W. Ewert, D. J. Chavez, \& A. W. Magill (Eds.), Culture, conflict, and communication in the wildland-urban interface (pp. 99-108). Boulder, CO: Westview Press. 
Baas, J. M. (1992). Identifying service delivery strategies for ethnically diverse users of a wildlandurban recreation site. In D. J. Chavez (Ed.), Proceedings of the Symposium on Social Aspects and Recreation Research (General Tech. Rep. PSW-132, pp. 40-41). Albany, CA: USDA, Forest Service, Pacific Southwest Research Station.

Baas, J. M., Ewert, A., \& Chavez, D. J. (1993). Influence of ethnicity on recreation and natural environment use patterns: Managing recreation sites for ethnic and racial diversity. Environmental Management, 17, 523-529.

Blahna, D. J. (1992). Comparing the preferences of Black, Asian, Latino, and White fishermen at Moraine Hills State Park, Illinois. In D. J. Chavez (Ed.), Proceedings of the Symposium on Social Aspects and Recreation Research (General Tech. Rep. PSW-132, pp. 42-43). Albany, CA: USDA, Forest Service, Pacific Southwest Research Station.

Blahna, D., \& Black, K. (1993). Racism: A concern for recreation resource managers? In P. Gobster (Ed.), Managing Urban and High-Use Recreation Settings (General Tech. Rep. NC-163, pp. 111-118). St. Paul, MN: USDA, Forest Service, North Central Forest Experiment Station.

Brune, T. (1978, May). Chicago Park District shortchanges Black and Latino wards; More facilities, programs and staff channeled to White wards. The Chicago Reporter, 7, 1-3, 6.

Bullard, R. D., \& Wright, B. H. (1990). The quest for environmental equity: Mobilizing the AfricanAmerican community for social change. Society and Natural Resources, 3, 301-311.

Carr, D. S., \& Williams, D. R. (1993). Understanding the role of ethnicity in outdoor recreation experiences. Journal of Leisure Research, 25, 22-38.

Chavez, D. J. (1993). Visitor perceptions of crowding and discrimination at two National Forests in southern California (Research Paper RP-216). Albany, CA: USDA, Forest Service, Pacific Southwest Research Station.

Chavez, D. J. (2001). Managing outdoor recreation in California: Visitor contact studies 19891998 (General Technical Report PSW-GTR-180). Albany, CA: USDA Forest Service, Pacific Southwest Research Station.

Chicago Park District. (1989). Narrative of the lakefront users study data. Chicago: Chicago Park District.

Cranz, G. (1982). The politics of park design: A history of urban parks in America. Cambridge, MA: The MIT Press.

Dawson, D. (1991). Panem et circenses? A critical analysis of ethnic and multicultural festivals. Journal of Applied Recreation Research, 16, 35-52.

Delgado, A. (1994). Recreation preferences of Blacks/Latinos/Asians: A case study of Chicago's Park District minority planning and policy with focus on Lincoln Park. Unpublished doctoral dissertation, University of Illinois, Chicago.

Dwyer, J. (1994). Customer diversity and the future demand for outdoor recreation (General Tech. Rep. RM-252). Fort Collins, CO: USDA, Forest Service, Rocky Mountain Forest and Range Experiment Station.

Dwyer, J. F., \& Gobster, P. H. (1992). Black/White outdoor recreation preferences and participation: Illinois state parks. In G. Vander Stoep (Ed.), Proceedings 1991 Northeastern Recreation Research Symposium (General Tech. Rep. NE-160, pp. 20-24). Radnor, PA: USDA, Forest Service, Northeastern Forest Experiment Station.

Dwyer, J. F., \& Gobster, P. H. (1997). The implications of increased racial and ethnic diversity for recreation resource management, planning, and research. In W. F. Kuentzel (Ed.), Proceedings of the 1996 Northeastern Recreation Research Symposium (General Tech. Rep. NE-232, pp. 3-7). Radnor PA: USDA, Forest Service, Northeastern Forest Experiment Station.

Dwyer, J. F., \& Hutchison, R. (1990). Outdoor recreation participation and preferences for Black and White Chicago households. In J. Vining (Ed.), Social science and natural resource recreation management (pp. 49-67). Boulder, CO: Westview Press.

Floyd, M. (1999). Race, ethnicity and use of the National Park System. Social Science Research Review, 1(2), 1-24.

Floyd, M. F., \& Gramann, J. H. (1995). Perceptions of discrimination in a recreation context. Journal of Leisure Research, 27, 192-199.

Floyd, M. F., Shinew, K. J., McGuire, F. A., \& Noe, F. P. (1994). Race, class, and leisure activity preferences: Marginality and ethnicity revisited. Journal of Leisure Research, 26, 158-173. 
Gobster, P. H. (1992). Urban park trail use: An observational approach. In G. Vander Stoep (Ed.), Proceedings, 1991 Northeastern Recreation Research Symposium (General Tech. Rep. NE-160, pp. 215-221). Radnor, PA: USDA, Forest Service, Northeastern Forest Experiment Station.

Gobster, P. H. (1998a). Explanation for minority "underparticipation" in outdoor recreation: A look at golf. Journal of Park and Recreation Administration, 16, 46-64.

Gobster, P. H. (1998b). Urban parks as green walls or green magnets? Interracial relations in neighborhood boundary parks. Landscape and Urban Planning, 41, 43-55.

Gramann, J. H. (1996). Ethnicity, race, and outdoor recreation: A review of trends, policy, and research (Miscellaneous Paper R-96-1). Vicksburg, MS: US Army Corps of Engineers Waterways Experiment Station.

Gramann, J. H., Floyd, M. F., \& Saenz, R. (1993). Outdoor recreation and Mexican American ethnicity: A benefits perspective. In A. W. Ewert, D. J. Chavez, \& A. W. Magill (Eds.), Culture, conflict, and communication in the wildland-urban interface (pp. 69-84). Boulder, CO: Westview Press.

Hoots, T. A., \& Buist, L. J. (1982). Recreation opportunity spectrum: A new management concept. Trends, 17, 28-31.

Hutchison, R. (1987). Ethnicity and urban recreation: Whites, Blacks, and Hispanics in Chicago's public parks. Journal of Leisure Research, 20, 10-30.

Hutchison, R. (1988). A critique of race, ethnicity, and social class in recent leisure-recreation research. Journal of Leisure Research, 19, 205-222.

Kaplan, R., \& Talbot, J. F. (1988). Ethnicity and preference for natural settings: A review and recent findings. Landscape and Urban Planning, 15, 107-117.

Loewen, L. J., Steel, G. D., \& Suedfeld, P. (1993). Perceived safety from crime in the urban environment. Journal of Environmental Psychology, 13, 323-331.

Metro, L. J., Dwyer, J. F., \& Dreschler, E. S. (1981). Forest experiences of fifth-grade Chicago public school students (Research Paper NC-216). St. Paul, MN: USDA Forest Service, North Central Forest Experiment Station.

National Park Service. (1975). Gateway National Recreation Area New York-New Jersey. Special study: The 1974 summer season. New York: National Park Service.

People, Places, and Design Research. (1991). Recreation and leisure time study concerning the users and non-users of Lincoln Park. Chicago: Chicago Park District.

Schroeder, H. W., \& Anderson, L. M. (1985). Perception of personal safety in urban recreation sites. Journal of Leisure Research, 16, 178-194.

Scott, D., \& Munson, W. (1994). Perceived constraints to park usage among individuals with low incomes. Journal of Park and Recreation Administration, 12, 79-96.

Taylor, D. (1993). Identity in ethnic leisure pursuits. San Francisco: Mellen Research University Press.

Washburne, R. F. (1978). Black under-participation in wildland recreation: Alternative explanations. Leisure Sciences, 1, 175-189.

West, P. C. (1989). Urban region parks and Black minorities: Subculture, marginality, and interracial relations in park use in the Detroit metropolitan area. Leisure Sciences, 11, 11-28.

Woodard, M. D. (1988). Class, regionality, and leisure among urban Black Americans: The post-civil rights era. Journal of Leisure Research, 20, 87-105.

Zhang, T., \& Gobster, P. H. (1998). Leisure preferences and open space needs in an urban Chinese American community. Journal of Architectural and Planning Research, 15, 338-355. 